DOI: $10.1515 / \mathrm{abcsj}-2017-0011$

\title{
Detective Types and Criminal Minds
}

Barry Forshaw, ed., Crime Uncovered: Detective (Bristol: Intellect, 2016. 220 pp. ISBN 978-1-78320-521-9)

Fiona Peters and Rebecca Stewart, eds., Crime Uncovered: Antihero (Bristol: Intellect, 2016. 218 pp. ISBN 978-1-78320-5196)

Samantha Walton, Guilty But Insane: Mind and Law in Golden Age Detective Fiction (Oxford: Oxford U P, 2015. 304 pp. ISBN 978-019-872332-5)

The detective and the criminal are the most readily identifiable character types in detective fiction. No matter how blurred those figures' boundaries may become, readers of the genre approach their reading with these roles in mind. Intellect Books of Bristol UK recently introduced a series, "Crime Uncovered," that focuses on the character types of crime fiction. That fiction is broadly defined as encompassing not only literature but screen studies, that is, film, television and video games. The first two titles in the series, Detective and Antihero, will be discussed in this review. The third book, Samantha Walton's Guilty But Insane, rounds out the coverage by steadfastly looking at questions of criminals' guilt and culpability in the context of British Golden Age detective fiction of the 1920s through 1940s and shifting ideas about sanity, insanity and the functioning of the mind.

The Intellect titles are structured around "Case Studies" (chapters on individual fictional characters), "Interrogations" (interviews), and "Reports" (general, thematic essays). Antihero offers the more groundbreaking coverage, but both texts are notable for extensive attention given to contemporary (as recent as 2014) television programs from Europe and North America, programs that include Broen/Bron/ The Bridge, The Fall, Broadchurch, Luther, Forbrydelsen/ The Killing, True Detective, Dexter, and Ray Donovan. Detective is more European in focus with specialized chapters on police detectives featured in series from 
Spain, France, Sweden, Denmark, Sicily, Norway, as well as strong coverage of England and Scotland and, to a lesser degree, the USA. As might be expected in a book edited by Barry Forshaw, the coverage of recent writing in Scandinavia is particularly strong. Forshaw also conducted the four featured interviews (P.D. James, Henning Mankell, Ian Rankin and Robert Wilson). Detective is most notable for this breadth of coverage. Of the thematic essays, Gregorek's "The New Regionalism in Contemporary Television Police Drama" is perhaps the most interesting, while the Collins "case study" of detectives Sarah Lund and Saga Norén of Forbrydelsen/ The Killing and Broen/ Bron/ The Bridge, respectively, offers a good introduction to the series and characters in addition to adding some welcome context about contemporary relations between Denmark and Sweden.

Antihero also offers multimedia coverage, a strength of both texts, but its main focus is even more contemporary with Highsmith's Ripley and Thompson's Lou Ford being the old men of the lot. It may be this timeliness that gives the collection energy beyond that of Detective which covers series detectives who have been around for decades, but Antihero extends to cover even an antihero born of the Marvel Universe of comic characters ("The Punisher") and far more coverage of women, as criminal antiheroes (Alice Morgan of Luther), non-police investigators, (Kristeva's feminist, intellectual antihero, Stephanie Delacour), and the extensively flawed police detective of the North American version of Forbrydelsen/ The Killing (Sarah Linden). Walderzak's chapter on Linden could be read in conjunction with the essay by Collins in Detective to construct an investigation into the question of "Why female antiheroes and why now?" for further study. This essay, though, is illustrative of a distracting and irritating problem experienced with both texts: editing errors. Some of these misdemeanors are undoubtedly down to word processing software's auto-complete, but that is no excuse. Inconsistencies in spelling names (Who authors one of the essays, Jackie or Jacky Collins? Journalist Emily Nussbaum is referred to as Nessbaum throughout one essay and in its citations. Jane "Tennyson" is not the name of the Helen Mirren's character in Prime Suspect. And while there may be a "Colombia" University Press in that country, it is the Columbia University Press in New York City that is wanted here), errors in titles (Blanche on the Lamb for Blanche on the Lam appears more than once), use of incorrect word 
forms ("annuls" for instance, instead of "annals," "bares" for "bears"). It's enough to drive a literate person mad.

There are no such problems with Guilty But Insane. This is a beautifully-written, soundly-researched and (apparently) carefully-edited study that reveals new depths in Golden Age detective fiction and affords readers an education in nineteenth- and early twentieth-century British approaches to insanity, the functioning of the mind, and questions of criminal culpability. Golden Age fiction is firmly situated both in the narrative of the development of detective fiction and within the discourses of the legal system, medicine, psychology, and the intellectual milieu of modernism. Walton's point that changing public notions about criminal behavior and culpability altered the ways in which detective work was depicted in fiction is a very significant idea with continuing relevance to post-Golden Age detective fiction. In chapters that alternate historical and theoretical discussion with case studies of well-known and less familiar Golden Age texts, that idea is tested and convincingly demonstrated.

Along the way, several stated and unstated goals are achieved. Readers' understanding of texts that may have appeared merely conservative and detached from issues of the day are shown to be, while still conservative, actively participating in interwar discourses about the mind and the self, subjectivity and reason. The intellectual profile of Golden Age fiction, and detective fiction more generally, is elevated and less-studied texts of the period are revived. Sayers, Allingham and Christie receive extensive coverage, but works by Gladys Mitchell, Michael Innes, Christianna Brand and others are granted significant attention. While Walton's approach does not necessarily revolutionize readers' understanding of this fiction, it complicates it. The methods she employs to analyze the pressure exerted on the portrayals of detectives and their methods by changing ideas about social deviance, particularly as understood by the mass public, are a welcome addition to the tools of contemporary crime fiction criticism and could usefully be applied in the current day.

REBECCA MARTIN, Pace University 